\title{
Nuoret, työ ja tulevaisuus poikkeusaikana
}

Koronaviruksen aiheuttama poikkeustilanne näyttää jatkuvan kuukausia, myös tämän lehden numerosta toiseen. Virus vaikuttaa tavalla tai toisella jokaisen yksilön ja ryhmän arkeen. Pitkäaikaisvaikutuksia pohdittaessa keskustelussa on kiinnitetty huomiota erityisesti nuoriin. He ovat huolissaan ja heistä ollaan huolissaan, eikä aivan syyttä.

Koronakevät on jo lisännyt nuorisotyöttömyyttä selvästi. Varsinkin palvelualoilla työskennelleitä nuoria naisia on joutunut työttömäksi ja lomautettu. Teollisuuden työpaikat voivat olla vakavamman kriisin kohteena seuraavaksi. Nuorten kesätöitä on peruuntunut ja työkokemusta sekä suhteita jäänyt saamatta. 1990-luvun laman aikaan työmarkkinoille astumassa olleiden nuorten aikuisten työurat "arpeutuivat". Laman haavat paranivat, mutta pysyviä arpia jäi, eli huonossa taloustilanteessa valmistuneiden tulo- ja urakehitys on ollut muita heikompaa. Tästä kirjoitettiin esimerkiksi Työelämän tutkimus -lehden katsauksessa numerossa 2/2019. Myös vuonna 2008 alkaneen finanssikriisin jälkeen nuorten työmarkkinapositiot jäivät pitkäksi aikaa heikoiksi. Saman tyyppinen työurien arpeutuminen ja sen pitkäkestoiset vaikutukset voivat osua korona-aikaan valmistumassa olevien kohdalle.

Yliopisto-opiskelijoita opettaessaan ja ohjatessaan saa tuntumaa yliopisto-opiskelijoiden reaktioista poikkeustilanteessa. Tunnelmat tuntuvat kiristyneen, vaikka reaktiot riippuvat luonnollisesti monesta muustakin seikasta, kuten elämäntilanteesta niin sanottuna normaaliaikana. Ajatukset muuttuvat ajassakin. Vaikka olisi kuulunut niihin onnellisiin, jotka kevään kuukausina kokivat opiskelun omassa rauhassa tehokkaana, pakotetun kotonaolon jatkuessa mieliala voi laskea, varsinkin jos taloudelliset huolet ja tulevaisuuden työllistyminen painavat. Erilaisissa töissä, oppilaitoksissa sekä koulutuksen ja työelämän ulkopuolella olevien nuorten kokemukset ovat kaikki omanlaisiaan. Kuitenkin koronasta tullee sukupolvikokemus muuten yhä epäyhtenäisemmälle ikäluokalle. **

Tästä numerosta eteenpäin lehden kirja-arviotoimittajana aloittaa YTM Ville-Aleksi Valli. Hän tekee Suomen Kulttuurirahaston Pirkanmaan maakuntarahaston apurahalla väitöskirjaa Tampereen yliopiston sosiologian oppiaineeseen. Tutkimuksen aiheena on yksityisen turvallisuusalan työt ja turvallisuuden tuotanto palveluteollisuudessa. Tervetuloa tekijäjoukkoon! Edellistä kirja-arviotoimittajaa, YTT, tutkijatohtori Maija Mänttäri-van der Kuipia kiitämme ansiokkaasta panoksesta lehteen kuluneiden vuosien aikana.

Käsillä olevaan numeroon mahtuu runsaasti asiaa artikkelien, katsausten ja kirja-arvioiden muodossa. Katsaus-osastolla on mukana myös kolme esittelypuheenvuoroa erilaisista työelämäopetusta tarjoavista opintokokonaisuuksista kolmessa oppilaitoksessa: Tampereen ja Jyväskylän yliopistoissa sekä Humanistisessa ammattikorkeakoulussa Helsingissä. Opintojen si- 
sällöt ovat monitieteisiä, mutta niissä painottuu laaja-alainen yhteiskuntatieteellinen osaaminen.

Artikkeleista ensimmäisessä Kaisa Haapakoski ja Leena Åkerblad analysoivat, miltä suomalainen työelämä näyttää työllistymistä edistävän ammatillisen kuntoutuksen eri osapuolten eli kuntoutujien, omaohjaajien ja työantajien esittämänä. Kirjoittajat keskittyvät erityisesti toivoon ja optimismiin, jotka on aiemmassa tutkimuksessa todettu merkityksellisiksi työhönpaluun kannalta. Vaikka kuntoutujien asema on monesti hankala, toivat he haastatteluissa esiin myös myönteisiä näköaloja suomalaiseen työelämään ja sen tulevaisuuteen. Kirjoittajat kuvaavat tätä myönteisyyttä realistisen optimismin käsitteen avulla ja toteavat, että meillä ei ole vielä riittävästi tietoa tekijöistä, jotka edistävä realistisen optimismin syntymistä ja ylläpitämistä ammatillisen kuntoutumisen osana.

Kirsi Lappalaisen ja Hanna Hakulisen artikkelin aihe on työttömien terveyspalvelujen kehittäminen. Artikkelissa hyödynnetään arviointiprosessissa tuotettua, moninaista aineistoa, ja siinä huomioidaan niin asiakkaiden, viranomaisten, hanketoimijoiden, päättäjien kuin yhteistyönkin näkökulmat. Kirjoittajat toteavat, että työttömien terveyspalvelujen yhteistyöverkosto toimii satunnaisesti, ja siksi yhteistyön tiivistämistä ja pysyviä rakenteita tarvitaan. Lisäksi asiakas tulee osallistaa oman terveytensä, työkykynsä ja työllistämisensä prosessiin nykyistä paremmin. Kolmanneksi he toteavat, että työttömien terveyspalveluja on kehitetty pitkälti hanketoimintana, mutta yhteistyöverkostojen pitäisi olla pysyviä, toimivia ja moniammatillisia.

Marjatta Takala ja Minna Saarinen perehtyvät opettajien toimijuuten yhteisopettajuudessa eli tilanteessa, jossa useampi kuin yksi opettaja opettaa yhdessä. He kysyvät, mitä luokan-, aineen- ja erityisopettajat kertovat yhteisopetuksesta asiantuntijakeskusteluissa ja miten opettajan toimijuus toteutuu yhdessä opetettaessa. Tulosten mukaan yhteisopetus koetaan hyvänä asiana, mutta tietyin reunaehdoin. Esimerkiksi fyysiset tilat eivät aina tue yhteisopetusta, kun kahta luokkaa ei voi yhdistää. Kuitenkin yhteisopettajuus on yksi mahdollisuus rakentaa ja vahvistaa koulua ammatillisen kehittymisen yhteisönä. Yhteisopettajuuden edellyttämän yhteistyön osapuolet hyötyivät siitä, sillä kumpikin opettaja oppi kollegalta ja kehittyi ammatillisesti. Yhteisopetus on taito, jota voi kehittää ja joka on etu työmarkkinoilla.

Jenna Ryynänen, Anniina Simonen ja Petri Karkkola tarkastelevat psykologisten perustarpeiden eli autonomian, kompetenssin ja yhteenkuuluvuuden välittävää roolia valtuuttavan johtamisen ja työntekijöiden kokeman työn imun välillä. Valtuuttavalla johtamisella he tarkoittavat esihenkilöiden johtamiskäytäntöjä, joilla pyritään tietoisesti lisäämään työntekijöiden vaikutusmahdollisuuksia, vastuuta ja vapautta. Artikkelissa hyödynnetään ASLAK-kuntoutukseen osallistuneille tehtyjä, itsearviointiin perustuvia kyselyjä. Tutkimuksen tulosten mukaan valtuuttava johtaminen tukee esihenkilöiden johtamiskäytännöstä eniten työntekijöiden autonomiaa. Yksittäisistä psykologisista perustarpeista autonomia oli ainoa, jonka kautta välittyi valtuuttavan johtamisen yhteys työn imuun. Kirjoittajat myös kyseenalaistavat tulosten perusteella yleisen suomalaisen työasenteen ja ankaran työetiikan, joiden mukaan työssä ei tarvitse viihtyä ja työpaikalla tulisi välttää sosiaalista seurustelua.

Antoisia lukuhetkiä lehden parissa! 